\title{
ON THE THEORY \\ OF THE MARGIN OF APPRECIATION DOCTRINE
}

\author{
Adam Wiśniewski ${ }^{\star}$
}

\section{Introduction}

The margin of appreciation doctrine is regarded as one of the most controversial among the principles, methods or techniques used by the European Court of Human Rights (Court or ECtHR) for interpreting and applying the European Convention on Human Rights (Convention or ECHR). The doctrine is often criticised and some of its critics even argue that the Court should abandon it. This study is based on the assumption that much of the criticism of the Strasbourg doctrine is directed against its improper use by the Court rather than against the doctrine itself. It appears that the real nature of the doctrine is often misconceived. I argue that the doctrine may be understood as the form in which this discretion exercised by national authorities is recognized and at the same time permitted by the Court (and earlier, by the Commission of Human Rights) in the process of interpreting and applying the Convention. Therefore, one should distinguish between the notion of margin of appreciation in the sense of the discretion which state-parties exercise when applying the

* University of Gdańsk. 
Convention's provisions and, alternatively, the doctrine of the margin in the sense of a certain construction which the Court uses to accommodate this discretion in the process of interpreting and applying the ECHR.

Moreover, the Strasbourg doctrine has a number of other functions which should be taken into account in order to properly evaluate its significance. I also argue that one of the purposes of the theoretical analysis of the doctrine could be to propose a model construction of the doctrine in order to assist the Court to take advantage of its potential bearing in mind that, simultaneously, criticism of the Court's use of the doctrine is necessary in order to prevent its inconsistent, façade-like and unprincipled application.

\section{The critique and the defence of the margin of appreciation doctrine}

In the debate over the margin of appreciation doctrine it is possible to distinguish at least three kinds of attitudes toward this doctrine. The proponents of the first approach, which may be termed as radical, call for the abandonment of the doctrine altogether. They describe the doctrine as an expression of resignation and opportunism or as an abdication by the Court of its duty to adjudicate in difficult or sensitive cases $^{1}$. Moreover, it is argued that its use has led the Court to dilute many of the strict conditions laid down in the Convention itself ${ }^{2}$.

In his often cited opinion about the doctrine, Lord Lester compared it to a slippery eel:

The concept of the "margin of appreciation" has become as slippery and elusive as an eel. Again and again the Court now appears to use the margin of appreciation as a substitute for coherent legal analysis of the issues at stake ... The danger of continuing to use the standardless doctrine of the margin of appreciation is that ... it will become the source of a pernicious "variable geometry" of human rights, eroding the "acquis" of existing

1 Zob. P. Mahoney, Marvellous Richness of Diversity or Invidious Cultural Relativism?, Human Rights Law Journal 1998, Vol. 19, No. 1, at p. 1.

2 Supra. 
jurisprudence and giving undue deference to local conditions, traditions, and practices ${ }^{3}$.

This radical attitude is also shared by some of the judges of the Court. In the partly dissenting opinion in the case $Z$. v. Finland Judge de Meyer entreated the Court to abandon the doctrine, claiming that "it is high time for the Court to banish that concept from its reasoning". De Meyer criticized the doctrine, first of all, for the relativism it implies. Although, according to Meyer, it is acceptable in certain domains, such as the determination of a criminal court sentence, when it comes to the sphere of human rights "there is no room for a margin of appreciation which would enable the States to decide what is acceptable and what is not. On that subject the boundary not to be overstepped must be as clear and precise as possible. It is for the Court, not each State individually, to decide that issue, and the Court's views must apply to everyone within the jurisdiction of each State". De Meyer also criticized the Court for deploying the margin of appreciation as an "empty phrase" repeated in judgments "for too long already (...) serving only to indicate abstrusely that the States may do anything the Court does not consider incompatible with human rights. Such terminology, as wrong in principle as it is pointless in practice, should be abandoned without delay"4.

One of the basic arguments against the margin of appreciation doctrine laid down by proponents of the first approach is that it is inconsistent with the very idea of human rights depriving individuals of the protection to which they are entitled under the Convention ${ }^{5}$. Given its unsystematic fashion of application and its unclear character, it contradicts the concept that clear and precise interpretation is essential for the effective enforcement of human rights ${ }^{6}$. It is also suggested that the doctrine's propensity to decentralize the Convention's standards by deferring to local values stands

3 Lord Lester of Herne Hill, QC, The European Convention on Human Rights in the New Architecture of Europe: General Report, Proceeding of the $8^{\text {th }}$ International Colloquy on the European Convention on Human Rights, CEP 1995, p. 236-237.

4 Partly dissenting opinion of Judge de Meyer in the Court's judgment in Z. v. Finland 25/02/1997 r., Reports 1997-I application No. 22009/93, point III.

5 Y. Arai-Takahashi, The Margin of Appreciation Doctrine and the Principle of Proportionality in the Jurisprudence of the ECHR, Intersentia, Antwerp-Oxford-New York, 2002, at p. 233.

6 Supra, p. 233. 
in contradiction to the idea of harmonizing European standards and, ultimately, universal standards of human rights ${ }^{7}$. Critics of the doctrine also claim that it lacks any legal basis in the Convention provisions and that when the Court decides, on the basis of this doctrine, that no violation of the Convention has occurred, this amounts to a denial of justice to the individuals concerned and defeats the cause of human rights ${ }^{8}$.

Proponents of the second kind of attitude towards the doctrine, which may be deemed a moderate approach, do not question the doctrine itself. However, they criticize the manner in which the doctrine is applied by the Court and highlight, in particular, its casuistic and unpredictable character $^{9}$. A former judge of the Court, G. van der Meerch, observed that existing case law is particularly unclear and varied as regards the elements on the basis of which the Court has decided whether or not to defer to the national authorities ${ }^{10}$. Consequently, moderate critics of the Strasbourg doctrine postulate the determination of the principles underlying this doctrine, understood in various ways. This refers in particular to principled criteria for its application ${ }^{11}$. As G. van der Meersch argues, it is necessary to specify the detailed and precise criteria for application of the doctrine in order to avoid the risk of over-extensive deference to national authorities ${ }^{12}$. Some authors also argue that a finding of non-violation of the Convention by the Court should not be decided solely by reference to the margin of appreciation doctrine without further explanation of the reasons underpinning the ruling. It is thus postulated that the court should provide convincing arguments whenever it decides to invoke the doctrine ${ }^{13}$.

7 Supra and P. Mahoney, op. cit., at p. 4.

8 P. Mahoney, op. cit., at p. 1.

9 See for example P. Greer, The Margin of Appreciation: Interpretation and Discretion under the European Convention on Human Rights, Human Rights Files 2000, No. 17, at p. 5.

10 W.J. Ganshof van der Meersch, Le caractère "autonome" de termes et la, marge d'appréciation' des gouvernements dans l'interprétation de la convention de Droits de l'Homme, [in:] F. Matscher, H. Petzold (edp.), 'Protecting Human Rights: the European Dimension. Studies in honour of Gerard J. Wiarda', Heymanns Verlag KG, Köln-Berlin-Bonn-München 1990, at p. 209.

11 Y. Arai-Takahashi, op. cit., at p. 18.

12 W.J. Ganshof van der Meersch, op. cit., at p. 208-210.

13 P. van. Dijk, G.J.H. van Hoof, Theory and Practice of the European Convention on Human Rights, Kluwer Law International, The Hague-Boston-London 1998, at p. 93. 
The third kind of attitude towards the doctrine is shared by those who defend the concept, treating it as justified in the case-law of the Court $\mathrm{t}^{14}$. For example, one of the Court's former judges, F. Matsher, criticized the view according to which the margin of appreciation doctrine constitutes an expression of resignation and opportunism. According to this author, the margin of appreciation doctrine is a realistic manifestation of "judicial restraint" and, understood in this manner, confirms with the Convention's provisions. It can be thus treated as one of the legitimate tools for interpreting the Convention ${ }^{15}$. Another author, R. Bernhardt, regarded the margin of appreciation as absolutely necessary in the implementation of the ECHR, provided that it is applied correctly ${ }^{16}$.

Critique of the Strasbourg doctrine often results from certain misunderstandings. The first concerns the situation in which the objects of criticism are in fact certain instances of the doctrine's application and not its essence. For example, the essence of such criticism is often that the doctrine is utilized as a façade or rhetorical figure instead of providing a principled, convincing justification for the judgement ${ }^{17}$. In such cases, the doctrine is used as a substitute for the missing, convincing substantiation of the ruling. This, however, relates to the use of the doctrine, and not the doctrine itself.

The second misunderstanding relates to a methodological assumption which often accompanies a particular reconstruction of the doctrine, as propounded by the relevant author. The essence of such criticism then concerns the selected manifestations of the doctrine's use or certain of its elements. For example, G. Letsas in his article "Two Concepts of the Margin of Appreciation", argued that the essence of the doctrine lies in its application to resolving conflicts between various rights and collective goods ("substantial concept of the margin of appreciation") and in determining the intensity of the Court's supervision ("the structural

14 P. Mahoney, op. cit., at p. 3-6, J. Schokkenbroek, The Basis, Nature and Application of the Margin of Appreciation Doctrine in the Case-Law of the European Court of Human Rights, Human Rights Law Journal 1998, Vol. 19, No. 1, at p. 30.

15 F. Matscher, Methods of Interpretation of the Convention, [in:] R.St.J. Macdonald, F. Matscher, H. Petzold (eds.), 'The European System for the Protection of Human Rights', Kluwer Academic Publishers, Dordrecht-Boston-London, 1993, at p. 78

16 R. Bernhardt, Thoughts on Interpretation of Human-Rights Treaties, [w:] F. Matscher, H. Petzold (eds.), op. cit. at p. 68.

17 Y. Arai-Takahashi, op. cit., at p. 232. 
concept of margin of appreciation") ${ }^{18}$. One should not, however, confuse the various function of the Strasbourg doctrine with the essence of the doctrine itself, which lies in allowing the national authorities a certain degree of discretion when applying the Convention, a point which Letsas seems either to overlook or to underestimate. Moreover, it does not seem justified to reduce application of the doctrine to merely two uses, taking into account other important functions that it has in the case law.

The arguments concerning the absence of a legal basis for the doctrine within the text of the Convention appear more convincing. In fact, none of the specific methods of interpreting the Convention, such as autonomous or dynamic interpretation, are mentioned in the provisions of the Convention or its protocols. It is relatively rare for legal systems to provide the rules of interpretation in legal acts. The codification of such rules in the Vienna Convention of the Law of the Treaties from 1969 is quite a distinct feature of public international law. However, none of the original methods of interpretation were provided in this Convention. Yet the legality of such methods is not questioned on this ground. Some authors defend the legality of the doctrine by indicating that the capacity to employ it seems to derive from the inherent power of international judicial bodies to determine their own procedures and to effectively exercise their jurisdiction ${ }^{19}$.

One of the most important arguments against the doctrine is that it contradicts the universality of human rights and that its application leads to the relativism of Convention standards. The first argument results from a misunderstanding which consists in equating universality with uniformity.

This misunderstanding can be explained by invoking the Vienna Declaration and Programme of Action from 1993 wherein point 5, which may be regarded as the manifestation of an understanding of the universality by the international community, after recognizing that all human rights are universal, indivisible and interdependent and interrelated, stated that "the significance of national and regional

18 G. Letsas, op. cit., p. 706. Letsas included this theoretical proposal in his book which was published later: A Theory of Interpretation of the European Convention on Human Rights, Oxford University Press, 2007.

19 Y. Shany, Toward a General Margin of Appreciation Doctrine In International Law, The European Journal of International Law 2006, Vol. 16, No. 5, at p. 911. 
particularities and various historical, cultural and religious backgrounds must be borne in mind". As J.A. Sweeney observed, those instances where the ECtHR takes into account the local and regional particularities of given states do not amount to a denial of universality ${ }^{20}$. The latter does not require uniformity, therefore national authorities exercising their margin of appreciation, "come too their own conclusions within a realistic, diffuse, universal concept of human rights" ${ }^{21}$. In this context, it is correct to perceive the margin of appreciation doctrine as a tool which enables the Convention's open norms to be endowed with contents that correspond to the nation's spirit confirming that the ECHR is an instrument which is flexible in nature and open to the cultural heritage of the various State Parties to the Convention ${ }^{22}$ or, wider, to the richness of the pluralism of European societies. By the same token, the Court's respect of pluralism in its European dimension is fully manifested.

It appears that the objection alleging that the doctrine introduces dangerous relativism is more difficult to rebut, since such a rebuttal would require, in particular, that the doctrine adopted a clear assumption that the essence of any right may not fall within the subject-matter of the margin of discretion. This is also closely related to the concept of the minimal standard protected under the ECHR.

Under the essence concept, it may be accepted that the State Parties may legitimately differ in their adherence to the Convention's obligations at the periphery of a given right, but that they may not do so as concerns the essence of that right. The use of this concept might contribute to reducing the relativism accompanying application of the doctrine. It also, however, entails, various theoretical problems including, inter alia, the issue of delimiting the essence and peripheries of any given right. This concept, it is submitted, may also be useful in the context of the problem of the variable threshold of compatibility with the ECHR and the absence of legal certainty, which is enhanced by the use of the Strasbourg doctrine.

20 J.A. Sweeney, Margins of Appreciation: Cultural Relativity and the European Court of Human Rights in the Post-Cold War Era, International and Comparative Law Quarterly 2005, Vol. 54, No. 2, at p. 469, 474.

${ }^{21}$ Supra, at p. 471.

22 C. Mik, Charakter, struktura i zakres zobowiązań z Europejskiej Konwencji Praw Człowieka, Państwo i Prawo 1992, No. 4, at p. 15. 
One of the issues connected with the application of the margin by national authorities is that it is not for such authorities to use the doctrine of the margin of appreciation, since this is reserved for the Court itself. These authorities, however, enjoy the margin left to them by the ECHR under the Strasbourg doctrine and the Convention provisions. Another important thing is that enjoyment of the margin is not a right which belongs to the States per se, since it is conditional upon the discretionary decision of the Court.

The margin of appreciation doctrine could be generally evaluated positively based on its positive functions in the process of the interpretation and application of the Convention. The doctrine should not be perceived merely as one of the tools of interpretation used by the Court. It also serves as an instrument modifying the Courts' supervision over the performance of duties flowing from the ECHR and, furthermore, it is used to regulate the position of the ECHR in relation to its sovereign State Parties. It also has the function of respecting choices made in the course of the democratic process at the national level, the function of respecting pluralism in the process of applying the Convention and the function of limiting the Court's law-making. Some of these functions merit positive evaluation, for example, the function of respecting pluralism and some not, for example, the rhetorical function. It can be argued that only by taking into account all positive functions of the doctrine in the Strasbourg case law, it is possible to properly grasp its significance in the process of the interpretation and application of the Convention.

Finally, an attempt to defend the doctrine could be based on arguments concerning the necessity of discretion implied by the general nature of Convention's provisions and the overall positive evaluation of the doctrine, considering in particular the various useful functions that it serves as an instrument used in the process of interpretation and application of the ECHR.

Moreover, one should not overlook the possibilities of regulating the inevitable national discretion that this doctrine offers. The doctrine is also welcomed by proponents of the pluralist concept of law. By taking into account the local variations, it allows, as P. S. Berman has observed, for some degree of diversity in the application of Convention standards ${ }^{23}$.

23 P.S. Berman, Global Legal Pluralism, Southern California Law Review 2006-2007, Vol. 80, No. 6, at p. 1202. 
The controversies and uneven, complex nature make the margin of appreciation doctrine both intriguing and a challenging object of theoretical analysis.

\section{The theoretical approach to the margin of appreciation doctrine}

There are at least two different approaches to the margin of appreciation theory. The first links the theoretical analysis of the margin of appreciation doctrine with certain "external" theories. This is the approach used, for example, by G. Letsas, who explains what he calls the "substantive concept of the margin of appreciation" by reference to moral theories of rights ${ }^{24}$. The second consists in making generalisations on the basis of the Strasbourg case-law. This is the approach adopted by, for example, by Ch. Yourrow and Y. Takahashi, who have authored two books on the margin of appreciation doctrine published in English ${ }^{25}$.

Ch. Yourrow, in his monograph entitled "The Margin of Appreciation Doctrine in the Dynamics of European Human Rights Doctrine" published in 1996, adopted the method of analyzing development of the doctrine and distinguished two periods during its evolution - before and after 1979. Yourrow analyzed the cases in a chronological order, dividing them into three groups. The first group includes cases connected with procedural guarantees (articles 5 and 6), whereas the second group concerns material provisions of the ECHR protecting personal freedoms, and the third group deals with the article 14 of ECHR on the prohibition of discrimination ${ }^{26}$. The author concludes by observing that the doctrine of margin of appreciation is a multifunctional tool in the hands of the Strasbourg institutions which, amongst other things, serves the purpose

24 G. Letsas, Two Concepts of the Margin of Appreciation, Oxford Journal of Legal Studies 2006, Vol. 26, No. 4, at p. 715-720.

25 See for example Ch. H. Yourrow, The Margin of Appreciation Doctrine in the Dynamics of the European Court of Human Rights Jurisprudence, The Hague-Boston-London 1996; P. Greer, The Margin of Appreciation: Interpretation and Discretion under the European Convention on Human Rights, Human Rights Files 2000, No. 17, Strasbourg, 2000; Y. AraiTakahashi, op. cit, at p. 14.

26 H. Ch. Yourrow, op. cit., at p. 24. 
of balancing the applicant's claims against the arguments raised by governments, in particular as regards articles 8 to $11^{27}$.

In an even more comprehensive study of the Strasbourg doctrine, entitled "The Margin of Appreciation Doctrine and the Principle of Proportionality in the Jurisprudence of the ECHR", Y. Arai-Takahashi based his analysis of this phenomenon on the assumption of its close relationship with the principle of proportionality. According to this author, the latter is the flip-side of the margin of appreciation in the sense that intensive reliance upon the proportionality principle corresponds with the narrower scope of the margin of appreciation. The bulk of Arai-Takahashi's book contains an analysis of the application of the margin of appreciation doctrine to various Convention rights (omitting, however, rights such as article 2 of Protocol I or article 2 of Protocol 4). The purpose of this analysis is to identify particular factors or variables determining the scope of the margin of appreciation with regard to particular Convention Rights. Whilst concurrently analyzing various fields of the application of the doctrine, Arai-Takahashi attempts to identify policy grounds pursued in the case-law of ECtHR ${ }^{28}$.

Any attempt to construct a theory of the margin of appreciation should not disregard the fundamental assumptions and principles upon which the Convention was founded. The aim of the ECHR is to protect human rights. It is, however, based on the principle of subsidiarity, assuming that the protection of his rights is, primarily, the responsibility of national authorities. It should also be remembered that, as P. Mahoney pointed out, the Convention is based upon a certain political philosophy, which assumes that the best system of government for ensuring respect of fundamental freedom and human rights is political democracy ${ }^{29}$.

The margin of appreciation doctrine is often criticised for a lack of uniformity or coherent application ${ }^{30}$. It is therefore no wonder that one of the principal aims of the theoretical analysis of the famous doctrine could be to establish some order and coherence in its application ${ }^{31}$. It is

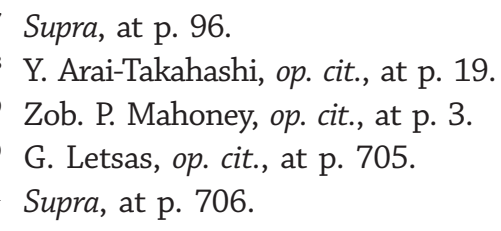


thus argued that one of the principal tasks of the theoretical analysis of the Strasbourg doctrine, apart from the issue of its theoretical foundations, should be the identification of a number of principles which may properly govern the use and the scope of the margin of appreciation ${ }^{32}$.

This is connected with attempts, undertaken by some authors, to analyse, in particular, the scope or width of the margin of appreciation, especially through the study of various factors affecting the actual scope of this margin ${ }^{33}$. No less important is research on the manner in which the Court exercises its supervision over the performance of the margin of appreciation by national authorities. Another group of issues concerns the problem of identifying the conditions affecting the scope of the application of the Strasbourg doctrine to various material provisions of the ECHR and its Protocols, the functions of this doctrine in the Court's adjudication, its role and position in the overall ECtHR's approach to the interpretation and application of the Convention. Any theoretical analysis of the doctrine should not omit the numerous controversies accompanying its use in the Strasbourg case-law as well as its justification and overall assessment.

One of the theoretical issues which seems to receive less attention in the debate over the margin of appreciation doctrine is the problem of the internal structure of this doctrine, the identification of its elements, their significance and mutual relationship. Authors dealing with this issue give various answers as to what principles or elements form part thereof or are connected with the doctrine of margin of appreciation. Y. Shany identified two elements of the doctrine, namely "judicial deference", which in particular implies respect for the discretion exercised by national authorities, as well as "normative flexibility" which is connected with the open-ended and unsettled character of international norms ${ }^{34}$. Y. Arai-Takahashi proposed the disaggregation analysis of the margin of appreciation doctrine. The basic components of the margin of appreciation include, according to this author, special deference for a national decision taken in "core" areas of sovereign authority; cases where the Convention test itself mandates deference,

32 J. Schokkenbroek, The Basis, Nature and Application of the Margin of Appreciation Doctrine in the Case-Law of the European Court of Human Rights, Human Rights Law Journal 1998, Vol. 19, No. 1, at p. 30.

33 See for example J. Schokkenbroek, op. cit., at p. 34-36.

34 Y. Shany, op. cit., at 909-910. 
or provides only very limited standards and guidance; the fourth instance doctrine and the principle of subsidiarity; and deference to "primary" democratic decisions in areas where fine value judgements are involved. He examined whether these elements disclose viable rationales and shed light on the hidden nature of the margin of appreciation ${ }^{35}$.

Other authors, observing that the limits of the margin of appreciation are affected by the facts and circumstances of a particular case, suggest an approach consisting in the search for the "common elements and rules" emerging from the whole of the case $\operatorname{law}^{36}$.

It seems natural that the purpose of the theoretical analysis of the Strasbourg doctrine should be the search for some order in its application. One of the possible contributions of theoretical studies of the margin of appreciation doctrine could be, however, to propose something more - a model construction of the doctrine, which could assist in making better use of its potential positive functions.

\section{The model construction of the margin of appreciation doctrine}

In the monograph entitled "The Concept of the Margin of Appreciation in the case-law of the European Court of Human Rights" published in Polish in $2008^{37}$, I adopted the approach based on the "inside approach", i.e. an approach which is grounded on the assumptions and elements of the doctrine which have been developed in evolving case law, initially of the Commission in the case Lawless v. Ireland from $1959^{38}$, and, later, by the Court in cases like Handyside, Sunday Times and many others ${ }^{39}$.

35 Y. Arai-Takahashi, op. cit., at p. 236.

36 E. Brems, The Margin of Appreciation Doctrine in the Case-Law of the European Court of Human Rights, Zeitschrift für Ausländisches Öffentlishes Recht und Völkerrecht 1996, Vol. 56, at p. 241.

37 A. Wiśniewski, Koncepcja marginesu oceny w orzecznictwie Europejskiego Trybunatu Praw Człowieka, Wydawnictwo Fundacji Rozwoju Uniwersytetu Gdańskiego, Gdańsk 2008.

38 The Report of the Commission in the case of G.R. Lawless v. Republic of Ireland from 19/12/1959, application No. 332/57, at p. 85.

39 See for example the judgements in: Handyside $v$. the United Kingdom from 07/12/1976, application No. 5493/72, at p. 49, Sunday Times v. the United Kingdom from 26/04/1979 r., application No. 6538/74, at p 59. 
This approach allows, first of all, for identification of the leading idea of the whole doctrine, its basic elements as well as justification.

The main idea of the doctrine was presented in a speech of $\mathrm{H}$. Waldock before the Court and in the Report of the Commission in the Lawless case. It consists in granting national authorities a certain discretion in the process of interpreting and applying the Convention. The justification for granting national authorities some degree of discretion is, first of all, their "better position than the Commission to know the relevant facts and to weigh the various considerations to be taken into account in deciding which of the different possible lines of action to adopt to dealt with the emergency" 40 .

Apart from the leading idea and justification of the margin of appreciation doctrine, in the Commission's Report in Lawless' case one can find the doctrine's basic elements exposed. First of all, it appeared that the margin of appreciation does not cover the whole of article 15 of ECHR, but merely specific matters involved in its application. For example, in the Lawless case it included only the determination by national authorities "whether there exists a public emergency which threatens the life of the nation and which must be dealt with by exceptional measures derogating from its normal obligations under the Convention" ${ }^{41}$. Secondly, the government's freedom of choice and margin of appreciation are not without limitations. As it was pointed out in the Commission's Report, they are limited by the obligations of international law, which the Irish Government accepted in ratifying the Convention ${ }^{42}$. Thirdly, the exercise of discretion by national authorities is subject to the Commission's supervision, which is competent to assess whether the government acted within the limits of the margin of appreciation that it was granted. The national discretion is thus limited and subject to supervision. Fourthly, the exercise of the margin of appreciation is connected with the burden of proof. As it was mentioned in Commission's Report, the "the burden of proof lies upon the State concerned to satisfy the Commission that a measure derogating from the Convention was one strictly required by the exigencies of the emergency at the time when was imposed"43.

\footnotetext{
40 Supra, at p. 115.

41 Supra, at p. 85.

42 Supra, at p. 85, opinion of professor A. Susterhenn, p. 149.

43 Supra, at p. 119.
} 
It is also for the first time in the Commission's Report in the Lawless case that the word "doctrine" was used in relation to the margin of appreciation of national authorities.

Thus, I argue that as early as the Lawless case it is possible to identify the essential group of components of the doctrine connected by one idea (i.e. allowing for some discretion of national authorities in the application of the ECHR) and suitably substantiated (i.e. the better position of the local authorities who know better local facts and considerations than the international court). The evolution of the doctrine in the case law of Strasbourg organs was connected with development of the internal elements of the doctrine, as well as the addition of certain new elements to it.

The elements of the doctrine, which I call "principles", include the following: the principle of specifying the material scope of the national authorities' margin of appreciation, the principles of the supervision over the margin of appreciation and respect for the national authorities' appreciation, the principle of the limits of margin of appreciation, the principle of the national authorities' burden of proof in connection with the margin of appreciation, the consensus principle, the principle of respect for specific circumstances concerning a given State Party to the Convention and the principle of the national authorities' "better position" (i.e. to assess local circumstances, evidence, etc.).

These respective principles are interrelated and also have various functions. The principle of specifying the material scope of the national authorities' margin of appreciation, of supervision over the margin of appreciation and its limits, of the national authorities' burden of proof in connection with the margin of appreciation, and the consensus principle serve the purpose of regulating the parameters of national discretion in the process of interpreting and applying the Convention. They could be regarded as the constitutive elements of the whole doctrine. Certain other principles also play a role in justifying the application of the doctrine. This refers primarily to the better position and consensus principles, as well as to the principle of respect for specific circumstances concerning a given State Party to the Convention. The aforementioned principles do not, by any means, exhaust the problem of justifying the application of the doctrine. It should, in particular, be remembered, that the doctrine is also based on the principle of subsidiarity ${ }^{44}$.

44 L. Garlicki, Wartości lokalne a orzecznictwo ponadnarodowe - „kulturowy margines oceny" w orzecznictwie strasburskim?, Europejski Przegląd Sądowy 2008, No. 4, at p. 5. 
The inclusion of certain elements in the internal construction of the margin doctrine may be contestable. This refers in particular to the consensus principle, which, at least to some extent, also appears in Strasbourg case-law independently of the margin of appreciation. However, it seems that inclusion of the consensus principle in the internal construction of the famous Strasbourg doctrine is, on the one hand, justified by its very close ties with the margin of appreciation and, on the other hand, serves well the explicatory purposes.

The proposed reconstruction of the margin of appreciation doctrine could be viewed as a proposal for a possible way of understanding and analysing this phenomenon. From a methodological point of view, this reconstruction is close to the modelling method, also well known in legal science ${ }^{45}$. It can, thus, be argued that this construction of the margin of appreciation concept constitutes a certain model based on essential features of the modelled phenomenon (derived from Strasbourg case-law) and application possibilities, including, in particular, its capability to provide explanation as to the application of the doctrine in the voluminous Strasbourg case-law.

The proposed model concept also provides an analytical framework for analysis of the Court's case law. Analysis of the application of the doctrine to various substantive provisions of the Convention, through the perspective of respective, identified principles of this doctrine, enables a better explication of its application by the Court, as well as facilitating an understanding of the aforementioned specificity of the doctrine's application to various Convention rights ${ }^{46}$. Nevertheless, one should bear in mind the problem of the coherence of the doctrine and the consequence of its application in case law. The proposed model concept of the Strasbourg doctrine may thus assist in answering the question about the existence or absence of the identity of the doctrine as applied to various substantive Convention provisions.

In the aforementioned book on the margin of appreciation concept, I conducted an analysis of the application of the margin of appreciation doctrine to the substantive provisions of the Convention and its

45 See more: J. Jabłońska-Bonca, T. Langer, On the Problems of Modelling in the Legal Science, Studies in the Theory and Philosophy of Law 1985, No. 1, at 6.

46 See more: A. Wiśniewski, op. cit., at p. 125-345. 
Protocols using the constitutional elements of the doctrine as parameters of the analysis. The identity of the doctrine, as applied to, in particular, such articles as 15, 8, 9, 1011 and 14 of the ECHR, was confirmed by the presence of the same basic, constitutive elements. On the other hand, the specificity of the use of the doctrine to various substantive Convention provisions is, in particular, manifested, by the absence of a uniform formula governing supervision over national authorities' margin of appreciation, variable limits of the margin, and sometimes diverse ways of setting these limits, or differences in setting the threshold of the burden of proof upon national authorities.

Considering the limits of the doctrine's expansion to substantive provisions of the Convention and its Protocols, it may be observed that the doctrine has so far not been applied in the case of rights protected by Articles 4 and 7, Articles 1, 3 and 4 of Protocol 4, and article 3 and 4 of Protocol 7. These are mostly rights formulated as a prohibition. This does not mean, however, that with regard to these provisions, the doctrine may not be applied - this potential application may be linked to the concept of positive obligations which are inferred by the Court from the substantive provisions of the ECHR. This, as well as the absence of one clear formula explaining the scope of the doctrine's application, makes it possible to argue that the assertion of some authors regarding the invasive and potentially unlimited scope of application of the doctrine to substantive provisions is not groundless ${ }^{47}$.

Permitting national authorities to exercise a certain degree of discretion in the application of the Convention through the doctrine of the margin of appreciation necessitated the regulation of such discretion, in order to reduce or eliminate arbitrariness on the part of national authorities. I propose to classify the factors regulating this discretion, under the Strasbourg doctrine, into two groups. The first comprises factors which are an integral part of the doctrine, including, first of all, the aforementioned constitutive elements. The second group includes external factors, which are taken into account, i.e. first of all, through the principle of limits on the margin of appreciation, but also,

47 R. St. J. Macdonald, The Margin of Appreciation Doctrine in the Jurisprudence of the European Court of Human Rights, [in:] International Law at the Time of Its Codification. Essays in Honour of Robert Ago, Dott. A. Giuffrè Editore, Milano 1987, at p. 192. 
inter alia, through the consensus principle and the principle of respect for specific circumstances concerning a given State Party.

Various factors determining the width of the margin are interrelated; they may also pull in opposite directions, and their particular configuration varies from case to case. Moreover, these factors also operate at different levels, and certain groups of factors seem to be of more relevance in the case of some of the rights than in the case of others - for example factors operating on the level of Convention principles are particularly influential as regards the right to freedom of expression, whereas political factors (which are often difficult to determine) perhaps have a strong influence in cases under article 15 of the Convention. It is therefore impossible to define the limits of the margin of appreciation by using one universally applicable formula.

Moreover, the crucial significance of the manner of supervision of the margin of appreciation for the regulation of national discretion should be emphasised - an issue which is sometimes overshadowed by considerations regarding the limits of national discretion.

One of the important issues about supervisions of the margin of appreciation is how exactly the Court respects the "appreciation" made by national authorities, declaring in its judgments that it "cannot substitute its own assessment for that of the national authorities". It follows from an analysis of the case law ${ }^{48}$ that it is possible to specify several different modes of supervising the national margin of appreciation by the Court. These include: supervision based on the test that the State exercised its discretion "reasonably, carefully and in good faith"; supervision based on the criterion of "manifest error of appreciation"; supervision using the formula "manifestly without reasonable foundation"; and supervision permitting the national authorities to merely undertake an initial assessment whilst final assessment is reserved for the Court itself. It is also possible to talk about the special character of supervision over the realisation of positive obligations by the State Parties. The level of supervision also depends, among other things, upon the intensity of the proportionality standard applied by the ECHR and upon its more active approach regarding fact-finding.

48 I mean here the analysis undertaken in the aforementioned study: A. Wiśniewski, op. cit., p. 125-345. 
The analysis of the Strasbourg case-law shows that there is no uniform manner of supervising the margin of appreciation and that the Court in fact uses various, sometimes overlapping, modes of supervision over national discretion, the use of a particular mode being dependent upon the particular Convention right at issue. Moreover, it is not always possible to discern how the Court respects, as it declares, national discretion or adheres to the declared non-substitution principle. The manner of supervising the margin of appreciation is adopted ad casum, depending also upon the circumstances of the case. This, however, means that the Court's approach to the issue of supervision is often unclear and, to some extent, also incoherent ${ }^{49}$.

Apart from the principle of limits on the margin of appreciation and of its supervision, the principle of specifying the material scope of the national authorities' margin of appreciation also serves the purpose of regulating their discretion. This is done by delimiting, at the outset as it were, the scope of a given substantive provision to which the applicable discretion is allowed. An important regulatory function is also performed by the burden of proof principle, which is imposed upon national authorities. All these principles are interrelated and serve a single purpose, namely regulating the national authorities' margin of appreciation and, hence, reducing their arbitrariness when enjoying the margin of appreciation.

The problem of the coherence of the doctrine is not only linked to the problems of setting the limits of margin of appreciation and establishing an applicable mode of supervision, but also to the relationship between the potentially contradictory consensus principle and the principle of respect for specific circumstances concerning a given State Party tothe Convention. Examining this problem at some length, the author first discusses the controversies and criticism concerning the consensus principle. The Court, using this principle, is accused, inter alia, of abdicating from its role of setting European moral standards ${ }^{50}$. On the other hand, the use of this principle leads to a dilemma as to what is more important to the Court - consensus or the national margin of appreciation.

49 See more, A. Wiśniewski, op. cit., at p. 352, 360-377.

50 E. Benvenisti, Margin of Appreciation, Consensus, and Universal Standards, New York University Journal of International Law and Politics 1998-1999, Vol. 31, No. 4, at p. 845. 
The important issue in the context of the conflict between the two principles relates to the conditions which must be fulfilled so as to permit the principle of respect for specific circumstances concerning a State Party to prevail over the consensus principle. This is primarily dependent upon the discharging of the burden of proof by a State Party, for example by convincing the Court that the asserted specificity arises not out of delay in adapting to the appropriate standards, but rather out of specific circumstances (cultural, political, historic) concerning this State Party. This, however, raises the issue of using the principle of respect for specific circumstances in order to avoid compliance with the Convention's provisions. In addressing this dilemma, the aforementioned concept of the essence and peripheries of a right might prove helpful.

One can argue that the nature of the discretion granted under the margin of appreciation doctrine, and the various dimensions of the margin, boil down to the assessments (for example of necessity of interference) and choices (for example of proper means) made by national authorities when applying the Convention's provisions. From a terminological perspective, the term "margin of appreciation" does not therefore correspond fully to the real subject-matter of the margin, and a better term would rather be "discretion of national authorities" or "margin of discretion". However, taking into account the strong roots of the terminology "margin of appreciation" in existing case law, no such alteration is likely.

One important issue which is also raised in connection with the margin of appreciation enjoyed by State authorities is whether the margin concerns merely application of the Convention's provisions and the application of the related assessments of facts, or whether it also extends to interpretation of the Convention's provisions? Some authors argue that the latter is excluded from the ambit of the margin ${ }^{51}$. It is, however, rather unthinkable that Convention provisions are applied in the absence of interpretation within the context of a specific case. It may thus be argued that, at least to some extent, national authorities enjoying the margin also interpret the Convention provisions. This refers, in particular, to those provisions containing indeterminate expressions and terms, such

51 J. Callewaert, Is there a Margin of Appreciation in the Application of Articles 2, 3 and 4 of the Convention, Human Rights Law Journal 1998, Vol. 19, No. 1, at p. 9. 
as "morality", which need to be filled by a specific content related to the circumstances of the case. National authorities are, however, bound by the standards stemming from the case law. Also, it should be remembered that the ultimate interpretation of the Convention's provisions rests with the Court.

One of the most fundamental tensions accompanying the application of the Convention relates to conflicts between the rights and interests of individuals and society, or between individuals and their rights and interests. The inclusion into the ambit of the margin of appreciation of the balancing of conflicting interests and rights by national authorities makes it possible for them to take into account, in the process of balancing and striking a fair balance, the local and specific circumstances appearing in a given case. However, it is difficult to find any uniform formula concerning the use of the concept in such cases in existing Strasbourg case law.

Another theoretical issue is connected with the significance of the doctrine in the Court's general approach to the interpretation and application of the Convention. An examination of the relationship between various principles and methods of interpretation and the Strasbourg doctrine indicates that such principles and methods do not constitute an uniform and coherent system but, on the contrary, give rise to tensions and conflicts between them. These internal contradictions seem to reflect the antinomies accompanying the application of the ECHR.

In all dimensions of these antinomies, and especially those between the rights of an individual and the interests of society, the ECHR's jurisdiction and the sovereignty of State Parties, the delivery of judgements at the level of Strasbourg, and the need for respect for democratic choices at the national level, as well as the aim of ensuring uniform human rights standards, on the one hand, and the need to respect pluralism among the State Parties, on the other hand - the margin of appreciation doctrine allows the Court a certain degree of flexibility.

Thus, the significance of the doctrine and its multifunctional character ensure that it goes far beyond the role of a mere tool of interpretation. Accordingly, it should rather be perceived as a principle in the process of implementation of the Convention. From this perspective, it is also possible to assess more adequately the proper significance of the margin of appreciation doctrine in the balancing process during which 
the Court considers various rationales and arguments before delivering judgements in the, very frequently, hard cases before it.

It can also be asserted that the use of the margin doctrine allows the Court to maintain the Convention system in a state of equilibrium in the face of the aforementioned tensions and antinomies, including restraints on law-making arising from the application of this doctrine. This, however, raises the question as to whether the need to maintain the system in a state of equilibrium does not threaten its stagnation. If the effects of the use of the doctrine are the retarding of the development of Convention standards and the introduction of relativism, this in turn raises the question of whether this doctrine may be found compatible with the very concept of human rights and, furthermore, what its perspectives are.

The doctrine of margin of appreciation concerns the discretion exercised by national authorities. However, undoubtedly the Court exercises its own discretion using this doctrine in the process of interpreting and applying the ECHR. The discretion of the ECtHR is constrained by certain procedural factors, as well as by substantive factors such as standards developed in its case law, principles of the ECHR as well as the need for its judgements to be rational and coherent with the Convention system.

Moreover, the impact of the constitutionalization of the ECHR on the use of the Strasbourg doctrine should be considered. If the Court is to give judgements of principle which are to build-up an European public order, then requirements as regards the doctrine of margin of appreciation and its use must be set at a higher level. This means, inter alia, that instead of sometimes rhetorical use of the doctrine, which may have the effect of degrading case-law, the Court should, in all cases in which it invokes the concept, explain clearly the influence it has exerted on the final ruling.

\section{Conclusion}

Although frequently criticised, the margin of appreciation doctrine has become a principle in the process of implementing the Convention which is well grounded in the Strasbourg case-law. It should be viewed from a proper perspective as a multifunctional and multidimensional instrument in the hands of the Court, used by it for interpreting 
and applying the Convention. The introduction of this concept to the Convention's acquis should be perceived not as an arbitrary exercise, but rather as a well-understood necessity considering the open and general character of the material Convention norms.

The margin of appreciation doctrine is perhaps not the only form of permitting national discretion as regards application of the ECHR. The proposed theoretical model of the margin of appreciation doctrine suggested in this study helps to illustrate that the Strasbourg doctrine, properly applied and understood, offers the possibility of multidimensional regulation of national authorities' discretion. This could enable a significant reduction, if not eliminate altogether, the latitude and arbitrariness of national authorities as regards the exercise of their margin of appreciation.

The ECtHR is essentially becoming the constitutional court for Europe and should fully utilize the potential of this important instrument but should, nevertheless, do so prudently and in a manner which is consistent both with the internal principles of the doctrine, as proposed in this study, and with the principles on which the whole Convention system is based, within "the general spirit of the Convention". Only through such an approach will enable the Court to ensure that the doctrine becomes an acceptable element of the Convention system. 